БІОМЕДИЦИНА

\title{
Investigation of DNA topoisomerase I as an autoantigen at the thyroid cancer
}

\author{
L. L. Sidorik, T. A. Rybkinska, O. G. Vigontina, M. I. Vudmaska, V. G. Naidenov, \\ P. V. Pogribnyi ${ }^{1}$, I. L. Lisovskii ${ }^{1}$, L. P. Schvachko, I. Bronstein ${ }^{2}$, V. V. Lyzogubov ${ }^{3}$, \\ E. A. Prihod'ko ${ }^{3}$, V. S. Usenko ${ }^{3}$, G. Kh. Matsuka
}

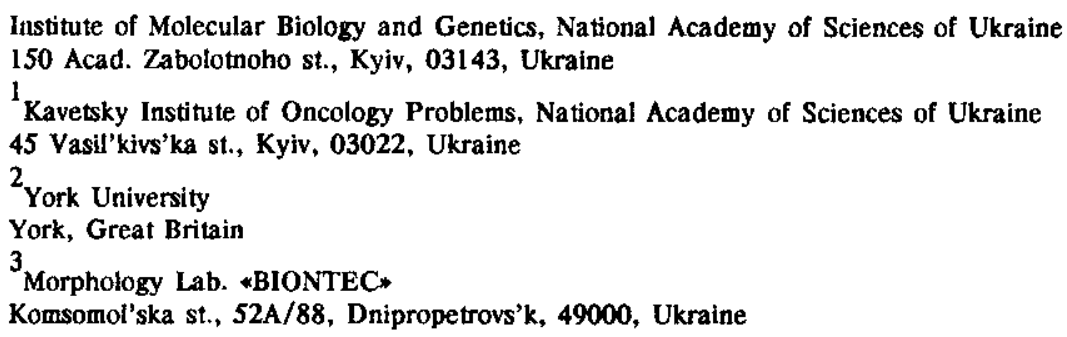

\begin{abstract}
The data concerning DNA-Topoisomerase I (Topo-I) from human placenta as an autoantigen at the thyroid cancer are presented. A new effective scheme of the Topo-I purification using the High-Trap columns is described, as well as the enzyme physico-chemical properties and its immunoreactivity in the ELISA and immunoblotting. It was shown that $46 \%$ of the sera from patients suffering the thyroid cancer were immunoreactive against Topo- $I, 36 \%$ of autoantibodies from thyroid cancer patients sera recognized sequential determinants on the Topo-I molecule. The highest levels of immunoreacivity were observed in the sera of thyroid cancer patients accompanied by autoimmune thyroiditis. We suggest a possible linkage between the autoimmune processes and malignization of the thyroid gland cells.
\end{abstract}

Introduction. Topoisomerases (Topos) are enzymes that modify and regulate DNA topological state. These enzymes participate in many cellular metabolic processes which are associated with the separation of complementary DNA strands such as replication, transcription, recombination and repair $[1,2]$.

Type I DNA topoisomerase (Topo I) was identified as a main cellular target for a wide variety of clinically relevant anticancer drugs: chemotherapeutical potentials of such drugs correlate with their abilities to stabilize covalent Topo-cleaved DNA complexes which are the reaction intermediates in the enzyme catalytic cycle. Physical basis for the clea-

(C) L. L. SIDORIK, T, A. RYBKINSKA, O, G. VIGONTINA,

M. I. VUDMASKA, V. G. NAIDENOV, P. V. POGRIBNYI,

l. L. LISOVSKII, L. P. SCHVACHKO, I. BRONSTEIN,

v. V. LYZOGUBOV, E. O. APOSTOLOV, v. $S$. USENKO,

G. Kh. MATSUKA, 2001 vable complex formation by the Topos-targeting drugs and mechanism by which the drugs alter the catalytic properties of Topos and convert these essential enzymes into lethal cellular weapons remain to be defined [3].

Topo I acts by making a transient single-stranded nick, passing another strand through the nick and changing the linking number by one unit. Recently the crystal structure of Topo I-substrate complex has been elucidated [4]. Topo I was described as the first nuclear autoantigen $\mathrm{Scl}-70$ in the scleroderma (Scl) patients (pts) $[5-8]$. A new imagine of a role of autoimmune processes in cancerogenesis [9-10] put forward a problem of detailed study of the Topo I peculiarities as of the autoantigen at different kinds of cancer.

Topo I was purified from human placenta nuclei. The purity and specificity of the Topo I preparation was determined by the gel-electrophoresis and Wes- 
tern-blot analysis. The enzymatic activity of Topo I was measured by the relaxation assay.

Sera immunoreactivity of 58 pts with thyroid cancer (TC) (including $12 \mathrm{TC}$ pts with accompanied thyroiditis), 26 pts with autoimmune thyroiditis (ATh) and 39 sera of healthy donors (HD) was examined by ELISA and Western-blot analysis. Human thyroglobulin (ThG) was used as a control antigen. 8 sera of Scl pts were used as a positive control for the Topo I autoantigen. $46 \%$ of TC sera were Topo I-positive and $32 \%$ of TC sera ThGpositive. The autoantibodies level against Topo I was significantly higer in TC pts than in ATh pts and HD. Western-blot analysis of TC pts sera revealed the presence of sequential determinants on the Topo I molecule as well as conformational ones which can suggest the role of Topo I as the autoantigen at TC inducing humoral immune response with the $B$ cell polyclonal activation.

Materials and Methods. Human placenta were received from a healthy woman in labour (a kind gift of Prof. D. R. Shadlun, The 1st Maternity Hospital, Kyiv). Monoclonal antibodies against DNA Topo I from calf thymus were developed by Prof. I. Bronstein (York University, United Kingdom).

Goat antibodies against rabbit IgG conjugated with horse radish peroxidase and anti-human IgG conjugated with peroxidase were from «Promega» (USA), hydroxylapatite (Bio-Gel HTP) and protein molecular weight standard were from «Bio-Rad» (USA), nitrocellulose BA-85 was from «Schleicher and Schull» (Germany), ECL reagent was from «Pierce» (USA), High-Trap column MonoQ and SPSepharose were from «Bio-Rad». Other reagents were purchased from «Sigma» (USA) and «Merck» (Germany).

Polyacrylamide gel electrophoresis in denaturating conditions was done according to Laemmli [11].

Protein concentrations were measured by the prow dure of Bradford [12].
Topo I purification. DNA-Topo I was purified from human placenta nuclei according to the method [13] with some modifications.

Nuclei from human placenta were purified as described in [13] with additional purification on a sucrose gradient. Nuclei were lized in buffer $A$ (150 mM K-phosphate, pH 7.0, $1 \mathrm{M} \mathrm{NaCl} \mathrm{,} 4 \mathrm{mM}$ EDTA, $1 \mathrm{mM}$ phenylmethylsulfonyl fluoride (PMSF), $1 \mathrm{mM}$ DTT, $20 \%$ glycerol and protease inhibitor cocktail) in the Potter homogenizer during $30 \mathrm{~min}$ with following addition of buffer $B$ for DNA precipitation (18\% PEG-6000, $1 \mathrm{M} \mathrm{NaCl}, 50 \mathrm{mM}$ K-phosphate, pH 7.0, $4 \mathrm{mM}$ EDTA, $1 \mathrm{mM}$ PMSF, $20 \%$ glycerol). The final mixture was centrifuged $30 \mathrm{~min}$ at $10000 \times \mathrm{g}$.

The supernatant obtained was chromatographed on the hydroxylapatite column equilibrated with buffer C (50 mM K-phosphate, $\mathrm{pH} 7.0,0.33 \mathrm{M} \mathrm{NaCl}$ ). After washing with buffer $\mathrm{D}(0.2 \mathrm{M}$ K-phosphate

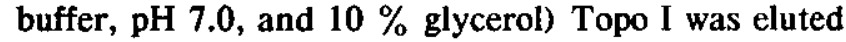
by the linear gradient of K-phosphate buffer $(0.2-$ $0.9 \mathrm{M})$ : the fractions containing Topo I were determined by the relaxation assay and Western-blot analysis.

The fractions containing the Topo I activity were pooled, diluted with equal volume of $10 \%$ (wt/v) glycerol/0.2 M NaCl/50 mM HEPES, pH 7.5, $1 \mathrm{mM}$ EDTA/1 mM PMSF, and chromatographed on the High-Trap SP-sepharose column, equilibrated with the same buffer. The enzyme was eluted by the linear gradient of $\mathrm{NaCl}(0.2-1.5 \mathrm{M})$.

The active Topo I fractions were pooled, dialized against buffer $\mathrm{C}$ and chromatographed on the HighTrap Mono $Q$ column equilibrated with buffer $C$.

The enzyme was eluted by the linear gradient of K-phosphate $(0.2-1.5 \mathrm{M})$. The Topo I-active fractions were pooled and kept at $-60{ }^{\circ} \mathrm{C}$ in $50 \%$ glycerol/K-phosphate buffer.

Topoisomerase assay. The Topo I activity was measured by relaxation of the supercoiled $p B R 322$ 


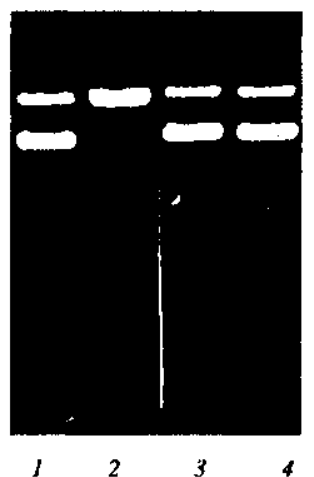

Fig. 2. Determination of the Topo I activity after the High-Trap SP-sepharose chromatography. Agarose-gel electrophoresis of the Topo I reaction products in different $\mathrm{KCl}$-gradient fractions: 1 - control $p B R 322$ without enzyme; $2-0.4-0.6 \mathrm{M} \mathrm{KCl}$ fractions (Topo I); $3-0-0.4 \mathrm{M} \mathrm{KCl}$ fractions (Topo I not detected); $4-0.6-0.8 \mathrm{M}$ $\mathrm{KCl}$ fractions (Topo II activity only)

plasmid DNA. The $20 \mu \mathrm{l}$ assay mixture contained $50 \mathrm{mM}$ Tris $/ \mathrm{HCl}$, pH 7.5, $120 \mathrm{mM} \mathrm{KCl}, 10 \mathrm{mM}$ $\mathrm{MgCl}_{2}, 0.5 \mathrm{mM}$ EDTA, bovine serum albumin $(30 \mu \mathrm{g} / \mathrm{ml}), p B R 322$ DNA $(20 \mu \mathrm{g} / \mathrm{ml})$ and various amounts of the enzyme. After $30 \mathrm{~min}$ incubation at $37{ }^{\circ} \mathrm{C}$ the reaction was stopped by the addition of $5 \mu 1$ $\mathrm{Na}-\mathrm{SDS}$ containing $0.25 \mathrm{mg}$ of bromophenol blue per $1 \mathrm{ml}$. The electrophoresis was performed as described in [14]. One unit of activity is an amount of Topo I that relaxes half of $p B R 322$ DNA under these conditions.

ELISA. Immunoreactivities of both pts and of HD sera were assayed as described in [15].

Western-blot analysis with ECL reagent was developed according to the firm protocol with the variations described in [16] including incubation with sera or natural autoantibodies (NAA) during $14 \mathrm{~h}$ at $t=25^{\circ} \mathrm{C}$ (because NAA possess a lower affinity than provocated ones).

Immune-affinity purification of NAA. The affine column with coupled antigen (human DNA-Topo I) was synthesized as described. NAA were purified from the pts sera by immune-affinity chromatography according to the method described earlier [17].

Results and Discussion. The results of the subsequent purification of the Topo I preparations are presented on the electrophoregram (Fig. 1, $A, B$ ). Fig. $1, A$, shows the SDS/polyacrylamide gel pattern of the proteins, purified from 4 different placentas, after the final purification step. The enzyme activity (Fig. 2) was associated mainly with the protein band of $M_{r}$ $100 \mathrm{kDa}$ - rather than with the $M_{r} 68 \mathrm{kDa}$ protein band characteristic of the peptide resulting from endogenous proteolysis. The $100 \mathrm{kDa}$ Topo I was successfully purified when the High-Trap columns chromatography was used at the final stage of the purification. This purification scheme developed by us allows to obtain preparative quantities of Topo I with a high level of purity and biological activity in less time comparing to the classical scheme [13]. It is very important in the case of investigation of the enzyme as autoantigen when there is a need of large quantities of the protein for immunoscreening, blotting procedures and the synthesis of affinity column for the following purification of natural autoantibodies. This method is very effective for obtaining native Topo I from higher organisms contrary to the all known producents of human Topo I developed on the basis of lower eukaryotes (such as the yeast) or baculovirus system with the processing and folding systems different from those of higher eukaryotes.

The results on the pts sera immunoreactivity determined by ELISA are presented in Fig. 3 and Table. We found that $46 \%$ of TC pts sera possessed the immunoreactivity level significantly higher than that of HD sera. In the ATh group Topo I was immunoreactive in $58 \%$ of pts sera.

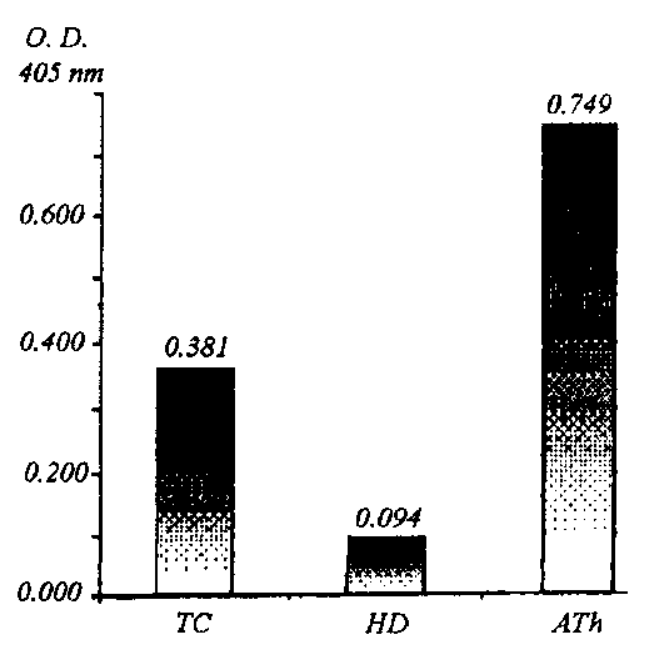

Fig. 3. Sera immunoreactivity of patients with the thyroid cancer (TC), autoimmune thyroiditis (ATh) and healthy donors (HD) negative control

Descriptive statistics (exper-t. sta)

\begin{tabular}{c|c|c|c|c|c|c}
\hline Diseases & Valtd N & Mean & Minimuw & Maximum & $\begin{array}{c}\text { Siandard } \\
\text { devtation }\end{array}$ & $\begin{array}{c}\text { Standard } \\
\text { error }\end{array}$ \\
\hline TC & 25000 & 0.361 & 0.150 & 1.081 & 0.182 & 0.036 \\
HD & 14000 & 0.094 & 0.019 & 0.287 & 0.081 & 0.022 \\
ATh & 10000 & 0.749 & 0.456 & 0.928 & 0.146 & 0.046 \\
\hline
\end{tabular}




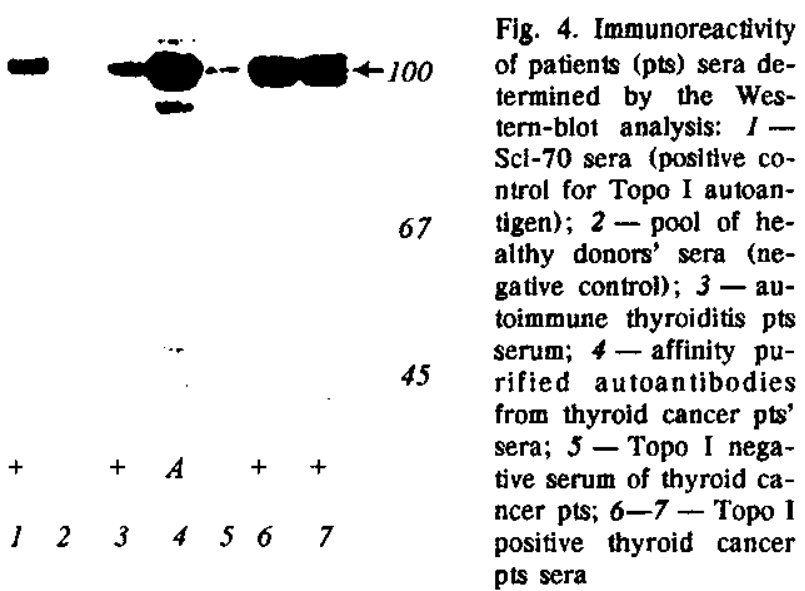

The monospecific NAA directed against Topo I were purified from TC, ATh and Scl pts sera and sera from HD by the immune-affinity chromatography on the column with coupled Topo 1. Fig. 4 represents the results of the Western-blot analysis which revealed the nature of antigenic determinants recognized by anti-Topo I NAA purified from the sera mentioned above. $36 \%$ of Topo I-positive sera of pts with TC and $63 \%$ of Topo I-positive sera of pts with Ath recognized both sequential and conformational epitopes.

The identification of anti-Topo I autoantibodies was described earlier in the sera of pts with the paraneoplastic neurological disease, ovary, lung and breast cancers $[10,18-20]$.

The present work is the first example of identification and characterization of the autoantibodies directed against Topo I in the sera of pts with the cancer of thyroid gland. The existence of NAA against Topo $I$ in the sera of pts with the cancer of thyroid gland and ATh points out close relations of the malignant processes with autoimmune pathology which often preceede the malignant transformation of cells in the target organ. Based on the long standing clinical data concerning a possible transformation of ATh into TC taken together with the presence of ATh in the anamnesis of some cancer pts, the suggestion can be made about the including of the autoimmune mechanisms in the development of certain types of cancer, particularly the cancer of thyroid gland. Obviously, this suggestion needs further investigations of the autoimmunity and cancer development as well as their relationship on the molecular level including Topo I.
Л. Л. Сидорик, Т. О. Рибкінська, О. Г. Вігонтіна, М. І. Вудмаска, В. Г. Найдьонов, П. В. Погрібний, І. Л. Лісовський, Л. П. ИІвачко, І. Бронитейн, В. В. Лизогубов, О. О. Приходько, В. С. Усенко, Г. Х. Мацука

Дослідження ДНК-топоізомерази I $\mathbf{9 x}$ аутоантигена при раку щитовидної залози

Резюме

Представлено дані з вивчення ДНК-топоізомерази I (Топо I), виділеної з плаценти людини, як аутоантигена при раку ицтовидної залози. Описано нову еффективну схему очищення Tопо I з використанням Нigh-Trap-колонок, фізико-хімічні властияості ферменту і його імунореактивність, визначену в реакцї ELISA та імуноблотингом. Показано, що Топо I-поэитивними виявилися $46 \%$ сироваток паціснтів з раком ицтовидної залози; $з$ них 36 \% містили аутоантитіла проти топо I, які розпізнавали антиzенні детермінанти секвенційного типу. Відмічено, що майбільи імунореактивними були сироватки пацієнтів з раком цитовидної залози $і$ супутнім аутоімунним тиреоїитом. Зроблено припущення щодо можливого зв'язку аутоімунних процесів із зооякісною трансформацією клітин цитовидної залози.

Л. Л. Сидорик, Т. А. Рибкинска, О. Г. Вигонтина,

М. И. Вудмаска, В. Г. Найденов, П. В. Погребной,

И. Л. Лисовский, Л. П. ПІвачко, И. Бронитейн,

В. В. Лизогубов, Е. А. Приходько, В. С. Усенко, Г. Х. Мацука

Исследование ДНК-топоизомеразы I как аутоантигена при раке щитовидной железы

Резюме

Предстаялены данные по изучению ДНК-топоизомеразы $I$ (Топо I), выделенной из плаценты человека, как аутоантигена при раке ициовидной железы. Описана новая эффективная схема очистки Топо I с применением Нigh-Trap-колонок, физико-химические свойства фермента и его иммунореактивность, определенная в реакции ELISA и иммуноблоттинге. Показано, что Топо 1-полохительными оказались $46 \%$ сывороток пачиентов с раком цитовидной железы; из них $36 \%$ садержали аутоантитела против Топо 1 , распознающие антигенные детерминанто секвенционного типа Отмечено, ито наиболее иммунореактивньми были сыворотки пациентов $с$ раком щитовидной железы и сопутствующим аутоиммунным тиреоидитом. Высказано предположение о возмохной связи аутоиммунных процессов со злокачественной трансформацией клетох цитовидной железы.

\section{REFERENCES}

1. Pommier Y., Pourquier P., Fan Y., Strumberg D. Mechanism of action of eukaryotic DNA topoisomerase I and drugs targeted to the enzyme (Review) // Biochlm. et biophys. acta.-1998.-N 1400.-P. 83-106.

2. Capranico G., Binaschi $M$. DNA sequence selectivity of topoisomerases and topoisomerase poisons // Biochim. et biophys. acta. -1998 . $-\mathrm{N}$ 1400.-P. 185-194.

3. Froelich-Ammon S. J., Osheroff N. Topoisomerase poisons: Harnessing the dark side of enzyme mechanism // J. Biol. Chem.-1995.-270, N 37.-P. 21429-21432.

4. Redinbo M. R., Stewart L., Champoux J. J., Hol W. G. J. Structural flexibility in human topoisomerase I revealed in multiple non-isomorphous crystal structures // J. Mol. Biol.1999.-292.-P. 685-696.

5. Shero J. H., Bordwell B., Rothfield N. F., Earnshaw W. C. 
High titers of autoantibodies to topoisomerase I $(\mathrm{Scl}-70)$ in sera from scleroderma patients // Science.-1986.-231.P. $737-740$.

6. Guldner H. H., Szostecki C., Vosberg H. P., Lakomek H. J., Penner E., Batz $F$. A. Scl-70 autoantibodies from scleroderma patients recognize a $95 \mathrm{kDa}$ protein identified as DNATopoisomerase I // Chromosoma.-1986.-94, N 2.P. 132-138.

7. Johanet C., Agastini M. M., Vayssairat M., Abuaf N. Anti-Scl70 and anticentromere autoantibodies. Biological markers of 2 forms of systemic scleroderma // Press Med.-1989.-18, N 5.-P. 207-211.

8. Kato T., Yamamoto $K$, Takeuchi H., Obebo M., Hara E., Nakada $S$., Oda $K$. Ito $K$. Nishioka $K$. Identification of an universal B-cell epitope on DNA Topoisomerase I, an autoantigen associated with scleroderma // Arth. Rheum.-1993.36, N 11.-P. 1580-1587.

9. Parmiani $G$. Tumor immunity as autoimmunity: tumor antigens include normal self proteins which stimulate anergic peripheral T cells // Immunol. Today. -1993. - 14, N 11.-P. 536-538.

10. Kyndt X., Habbar M., Querel V., Hachulla E., Hatron P. Y., Devulder $B$. Systemic scleroderma and cancer. Search for predictive factors of cancer in 123 patients with scleroderma // Rev. Med. Int. $-1997 .-18$, N 7.-P. 528-532.

11. Laemmli $U . K$ Cleavage of structural proteins during the assembly of the bacteriophage T4 // Nature.-1970.-227, N 5.-P. 680-685.

12. Bradford $M$. M. A rapid and sensitive method for quantitation of microgramm quantities of protein utilizing the principle of dye binding // Anal. Biochem. -1976. - 72, N 3.-P. 248254.

13. Duguet M., Lavenon C., Harper F., Mirambeau G., DeRecondo A.-M. DNA topoisomerases from rat tiver: physiologi- cal variations // Nucl. Acids Res. $-1983 .-11$, N 3.P. $1056-1075$.

14. Castora F. J., Kelly W. ATP inhibits nuclear and mitochondrial type I topoisomerases from human leukemia cells // Proc. Nat. Acad. Sci. (USA).-1986.-83, N 6.-P. 1680-1684.

15. Matsiota P., Druet P., Dasquet P. Natural autoantibodies in systemic lupus erythematosus // Clin. Exp. Immunol.-1987.69, N 4.-P. 79-88.

16. De Rooij D. J., Van de Putte L B., Habets W. J., Verbek A. $L$, Van Venrooij $W$. $J$. The use of immunoblotting to detect antibodies to nuclear and cytoplasmic antigens. Clinical and serological associations in rheumatic diseases // Scand. J. Rheumatol. -1988.-17, N 5.-P. 353-364.

17. Sidorik L L., Gudzera O. I., Dragovoz V. A., Tukalo M. A., Beresten $S$. $F$. Immuno-chemical non-cross-reactivity between eukaryotic and prokaryotic seryl-tRNA synthetases // FEBS Lett.-1991.-292, N 1, 2.-P. 76-78.

18. Moll J. W., Hooijkaas H., Van Goorbergh B. C., Roos L. G., Henzen-Logmans S. C., Vecht C. J. Systemic and antineuronal autoantibodies in patients with paraneoplastic neurological disease // J. Neurol. - 1996. -243, N 1.-P. 51-56.

19. Kuwana M., Fujii T., Mimori T., Kaburaki J. Enhancement of anti-DNA topoisomerase 1 antibodies response after lung cancer in patients with systemic sclerosis. A report of two cases // Arth. Rheum.-1996.-39, N 4.-P. 686-691.

20. Popazov G., Baleva R., Chavrakov G., Mendizov E. Case of Hashimoto's toxicosis with occult thyroid carcinoma // Vutr. Bol. $-1981 .-20$, N 5.-P. 105-117.

УдК 577.152

Надійшла до редакції 10.06.99 